\title{
Halotolerant bacteria in the São Paulo Zoo composting process and their hydrolases and bioproducts
}

\author{
Lilian C.G. Oliveira ${ }^{1}$, Patricia Locosque Ramos ${ }^{1,3}$, Alyne Marem ${ }^{1}$, Marcia Y. Kondo ${ }^{1}$, \\ Rafael C.S. Rocha ${ }^{1,4}$, Thiago Bertolini ${ }^{1}$, Marghuel A.V. Silveira ${ }^{2}$, João Batista da Cruz ${ }^{3}$, \\ Suzan Pantaroto de Vasconcellos ${ }^{2,3}$, Luiz Juliano ${ }^{1,3}$, Debora N. Okamoto ${ }^{1}$ \\ ${ }^{1}$ Departamento de Biofísica, Escola Paulista de Medicina, Universidade Federal de São Paulo, \\ São Paulo, SP, Brazil. \\ ${ }^{2}$ Departamento de Ciências Biológicas, Universidade Federal de São Paulo, Diadema, SP, Brazil. \\ ${ }^{3}$ Laboratório de Microbiologia Aplicada, Fundação Parque Zoológico de São Paulo, \\ São Paulo, SP, Brazil. \\ ${ }^{4}$ Koppert Biological Systems, Itapetininga, SP, Brazil.
}

Submitted: March 20, 2013; Approved: August 15, 2014.

\begin{abstract}
Halophilic microorganisms are able to grow in the presence of salt and are also excellent source of enzymes and biotechnological products, such as exopolysaccharides (EPSs) and polyhydroxyalkanoates (PHAs). Salt-tolerant bacteria were screened in the Organic Composting Production Unit (OCPU) of São Paulo Zoological Park Foundation, which processes 4 ton/day of organic residues including plant matter from the Atlantic Rain Forest, animal manure and carcasses and mud from water treatment. Among the screened microorganisms, eight halotolerant bacteria grew at $\mathrm{NaCl}$ concentrations up to $4 \mathrm{M}$. These cultures were classified based on phylogenetic characteristics and comparative partial 16S rRNA gene sequence analysis as belonging to the genera Staphylococcus, Bacillus and Brevibacterium. The results of this study describe the ability of these halotolerant bacteria to produce some classes of hydrolases, namely, lipases, proteases, amylases and cellulases, and biopolymers. The strain characterized as of Brevibacterium avium presented cellulase and amylase activities up to $4 \mathrm{M} \mathrm{NaCl}$ and also produced EPSs and PHAs. These results indicate the biotechnological potential of certain microorganisms recovered from the composting process, including halotolerant species, which have the ability to produce enzymes and biopolymers, offering new perspectives for environmental and industrial applications.
\end{abstract}

Key words: halophilic, protease, lipase, amylase, cellulase.

\section{Introduction}

The biocatalysts required in several industrial processes exhibit optimal activities at high ranges of salt concentration, $\mathrm{pH}$ and temperature. Halophiles are excellent sources of such enzymes and are found in nearly all major microbial clades, including prokaryotic (Bacteria and Archaea) and eukaryotic forms; two categories have been defined: halotolerant microorganisms that are adapted in live at high salinity, and halophiles that require salinity for growth. Halotolerant species tend to live in areas of salin- ity, such as hypersaline lakes, coastal dunes, saline deserts and salt seas (Ventosa and Nieto, 1995).

Halophilic enzymes perform the same enzyme function as their non-halophilic counterparts but require 1-4 M salt concentrations for their full activity and stability. In addition, these enzymes typically demonstrate a large excess of acidic amino acids compared to basic residues (Enache and Kamekura, 2010).

Proteases constitute approximately $66 \%$ of the total enzymes employed in biotechnological and commercial 
processes (Gupta et al., 2002), and the moderately halophilic aerobic bacteria of genera Bacillus, Pseudomonas, Halomonas and Serratia are important sources of proteases (Ventosa et al., 1998). Amylases are extensively studied due to their potential application in the food, detergent, paper and pharmaceutical industries, representing approximately $25 \%$ of the total enzymes in the industrial market. The extracellular production of $\beta$-amylase by halophilic Halobacillus sp. LY9 and of two $\alpha$-amylases from Chromohalobacter sp. has been reported ( $\mathrm{Li}$ and $\mathrm{Yu}, 2011$; Prakash et al., 2009). Cellulases also have industrial application, including the generation of bioethanol and in the textile industry, and a halotolerant cellulase was characterized in a soil metagenome analysis (Voget et al., 2006). Lipolytic enzymes are of particular industrial interest, and their identification in halophilic bacteria has been reported and recently reviewed (Gomez et al., 2012). Exopolysaccharides (EPSs) and polyhydroxyalkanoates (PHAs) are biotechnological products that were identified and produced from halophilic/halotolerant microorganisms (Legat et al., 2010; Litchfield, 2012).

In this sense, the Organic Composting Production Unit (OCPU) of SPZPF is a potential source of microorganisms, as demonstrated by an OCPU metagenomic analysis, which revealed a diversity of biomass degradation functions and organisms (Martins et al., 2013). The composting process is predominantly aerobic, with organic residues being degraded by microorganisms, generating a humus-like material. In recent years, composting has attracted attention as a viable and environmentally adequate alternative for the treatment of organic waste. The initial phase of composting is thought to be the most dynamic part of the process and is characterized by a rapid increase in temperature, a large change in $\mathrm{pH}$, and the degradation of simple organic compounds (Schloss et al., 2003). A detailed comparison of the bacterial diversity from different composting plants revealed a large difference at both the species and strain levels (Partanen et al., 2010).

This paper reports the screening of the composting process of OCPU at SPZPF for bacteria in the presence of a range of $\mathrm{NaCl}$ concentrations and also the evaluation of their potential for the production hydrolases and biopolymers. To date, the microbial diversity of this ecosystem has not been explored, particularly with regard to the screening of halotolerant microorganisms.

\section{Material and Methods}

\section{Bacterial strains and isolation of DNA}

\section{Composting process}

The composting process was conducted in the SPZPF OCPU in $2.5 \times 2.0 \times 1.6 \mathrm{~m}$ (lengthxwidthxheight) cells, as shown in Figure 1. The piles were formed by organic residues including food, droppings and excreta, the beds of native and exotic wild animals, carcasses and wood chips from gardening. The pile has decomposition phases that were considered active degradation (before aeration) and mature compost (after aeration). Pile aeration was achieved by the mechanical turning of the material after 50 to 60 days of composting. The temperature of the pile was monitored at five different points (four sides and one center). The average temperature of the pile at the time of collection was $50{ }^{\circ} \mathrm{C}$

\section{Microbial isolation}

Compost samples ( $10 \mathrm{~g})$ were collected from the piles and diluted in $90 \mathrm{~mL}$ of sterile water. Serial dilutions $(-2,-4$ and -6) were performed and spread on agar plates of two selective halophilic media: JCM n 377 medium $(10 \%[\mathrm{w} / \mathrm{v}]$ $\mathrm{NaCl}, 0.5 \%[\mathrm{w} / \mathrm{v}]$ casamino acids, $0.5 \%[\mathrm{w} / \mathrm{v}]$ yeast extract,

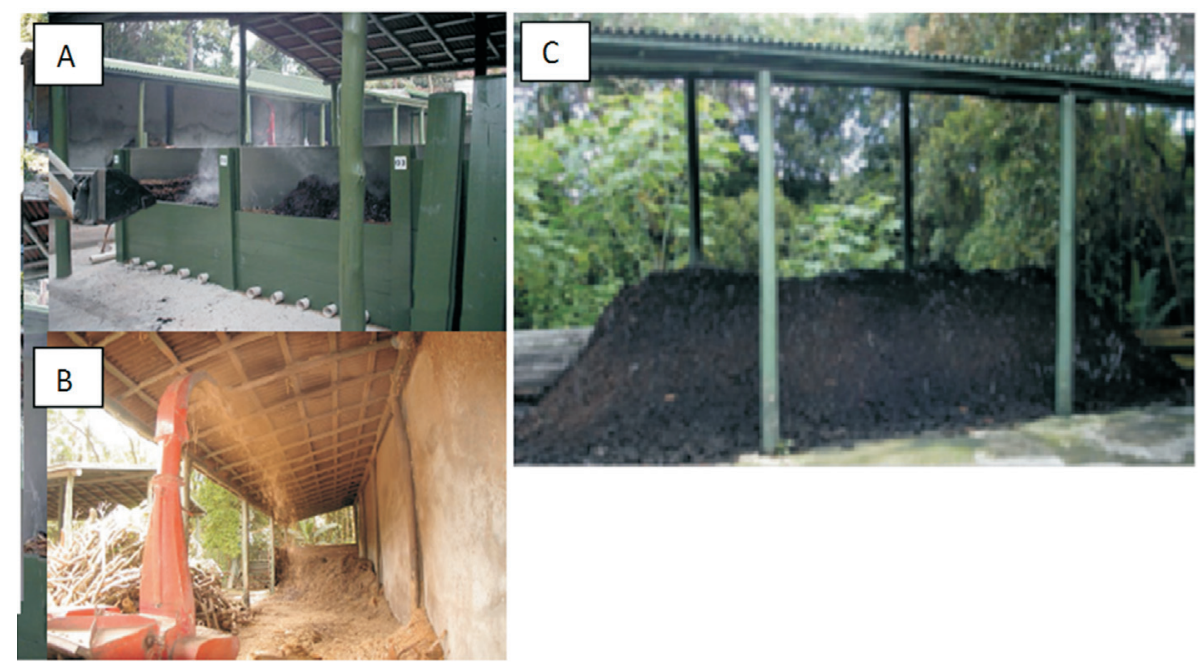

Figure 1 - Partial view of the Organic Composting Production Unit (OCPU) of São Paulo Zoological Park Foundation. (A) Aerobic composting process in the thermophilic phase; (B) grinding of plant matter from the Atlantic Rain Forest; (C) maturation phase of the composting process. 
$0.2 \%[\mathrm{w} / \mathrm{v}] \mathrm{KCl}, 0.3 \%[\mathrm{w} / \mathrm{v}]$ sodium citrate, $2 \%[\mathrm{w} / \mathrm{v}]$ $\mathrm{MgSO}_{4} \cdot 7 \mathrm{H}_{2} \mathrm{O}, 0.036 \%$ [w/v] $\mathrm{FeCl}_{2} 4 \mathrm{H}_{2} \mathrm{O}, 0.00036 \%$ [w/v] $\mathrm{MnCl}_{2} 4 \mathrm{H}_{2} \mathrm{O}$ and $2 \%$ [w/v] agar, $\mathrm{pH} 7.2$ ) and $\mathrm{YPC}$ medium $(0.5 \%[\mathrm{w} / \mathrm{v}]$ yeast extract, $0.1 \%[\mathrm{w} / \mathrm{v}]$ peptone and $0.1 \%$ [w/v] casamino acids with $60 \%[\mathrm{v} / \mathrm{v}]$ of salt water solution $24 \%$ [w/v] $\mathrm{NaCl}, 3 \%$ [w/v] $\mathrm{MgCl}_{2} 6 \mathrm{H}_{2} \mathrm{O}, 3.5 \%$ [w/v] $\mathrm{MgSO}_{4} \cdot 7 \mathrm{H}_{2} \mathrm{O}, 0.1 \%$ [w/v] KCl, $20 \mathrm{mM}$ Tris $\mathrm{HCl} \mathrm{pH} 7.5$ and $3 \mathrm{mM} \mathrm{CaCl}_{2}$ ) and incubated at 30,37 and $42{ }^{\circ} \mathrm{C}$. After 24 or $48 \mathrm{~h}$, the colonies were selected and transferred separately to obtain purified colonies.

\section{Screening of secreted extracellular hydrolytic activities}

Enzymatic agar plate assays were performed to detect the presence of extracellular hydrolases. All media were adjusted to $\mathrm{pH} 7.3$, and $\mathrm{NaCl}$ was added to obtain a salt concentration in the range of 0-4 M. The composition of the media used is described below.

\section{Determination of extracellular amylase activity}

Amylolytic activity on plates was determined qualitatively using a previously described method (Pascon et al., 2011), which was modified for halophilic microorganisms by adding $\mathrm{NaCl}$ in the medium. After incubation at $37^{\circ} \mathrm{C}$ for 5 days, the plates were exposed to iodine crystals for 5 min to reveal the starch degradation zone that indicates amylolytic activity.

\section{Determination of extracellular protease activity}

The cultures were screened in JCM n 377 medium and YPC medium supplemented with 1\% skim milk for the determination of protein hydrolytic activity. Clear zones around the colonies after 7 days were taken as evidence of proteolytic activity.

\section{Determination of extracellular lipase activity}

Lipase production by the isolated microorganisms was evaluated in nutrient agar tributyrin medium (NAT), which consisted of $1.3 \%$ nutrient broth, $1 \%$ tributyrin and 2\% agar (Ben-Gigirey et al., 2000). After incubation at 37 ${ }^{\circ} \mathrm{C}$ for 7 days, the hydrolytic zones around the bacterial colonies were considered an indication of lipase production.

\section{Determination of extracellular cellulase activity}

Cellulase activity was screened on a solid medium containing carboxymethyl cellulose (CMC) (Rohban et al., 2009). After incubation at $37^{\circ} \mathrm{C}$ for 7 days, the plates were flooded with $0.1 \%$ Congo red solution. The clear zone around colonies indicated cellulolytic activity.

\section{Screening of polyhydroxyalkanoates and exopolysaccharides}

\section{Detection of polyhydroxyalkanoate (PHA)-producing microorganisms}

The isolates were evaluated in mineral medium (Schlegel et al., 1970) with $2.5 \mathrm{M} \mathrm{NaCl}$ and containing glucose, xylose or octanoic acid as the carbon source. Glucose is known to be a carbon source for the production of short-chain-length PHAs, whereas octanoic acid produces medium-chain-length PHAs. Sugarcane bagasse contains xylose, and its excess is a promising substrate for producing by-products, such as second-generation bioethanol and PHAs (Lopes et al., 2009). After $24 \mathrm{~h}$ of incubation $\left(30^{\circ} \mathrm{C}\right)$, the isolated strains were evaluated for their ability to grow on these carbon sources; the isolates were stained with $\mathrm{Su}-$ dan Black B after $72 \mathrm{~h}$ to verify their potential to produce PHAs.

\section{Detection of exopolysaccharide (EPS) producers}

The isolates were cultivated in Bushnell Haas Salt Medium $(50 \mathrm{~mL})$ containing $2.5 \mathrm{M} \mathrm{NaCl}$ with glycerol as sole the carbon source for the microbial growth. After incubation for 5 days at $30{ }^{\circ} \mathrm{C}$ in a rotary shaker $(150 \mathrm{rpm})$, the cultures were centrifuged at 8,200 x $g$ for $15 \min \left(4^{\circ} \mathrm{C}\right)$. The emulsification index (E24) of the supernatant was evaluated according to the method described by Fleck et al. (2000) using hexadecane as a hydrophobic model compound. The chemical composition of EPSs precipitated from the supernatant with ethanol up to $70 \%$ was dialyzed against pure water, and carbohydrates, proteins and uronic acids were quantified in the retained high molecular weight fraction, as reported (Tanasupawat et al., 2010).

\section{Bacterial identification}

\section{Mass spectrometry}

The isolated microorganisms were treated with ethanol/formic acid for content extraction, following a previously described protocol (Pascon et al., 2011). Measurements were conducted with a Microflex LT mass spectrometer (Bruker Daltonics) using FlexControl software (version 3.0, Bruker Daltonics) in the positive linear mode (laser frequency, $20 \mathrm{~Hz}$; ion source 1 voltage, $20 \mathrm{kV}$; ion source 2 voltage, $18.6 \mathrm{kV}$; lens voltage, $7.5 \mathrm{kV}$; mass range, 2000 to $20000 \mathrm{Da}$ ). For each spectrum, 240 shots in 50 -shot steps from different positions of the target spot (automatic mode) were collected and analyzed. The spectra were internally calibrated using Escherichia coli ribosomal proteins. The raw spectra were imported into the BioTyper software (version 2.0, Bruker Daltonics) and processed by standard pattern matching with default settings; the results were reported in a ranking table. 
Amplification and sequencing of 165 rRNA gene fragment

DNA (30-50 ng) from each strain was incubated in a $50-\mu \mathrm{L}$ reaction mixture containing $2 \mathrm{mM} \mathrm{MgCl}_{2}, 200 \mu \mathrm{M}$ dNTPs, $\quad 0.3 \quad \mu \mathrm{M}$ universal primer $27 \mathrm{f}$ (5-AGAGTTGATCCTGGCTCAG-3), $0.3 \mu \mathrm{M} \quad$ 1525r (5-AAGGAGGTGWTCCARCC-3) and $2 \mathrm{U}$ Taq DNA polymerase (Invitrogen) in the recommended buffer. Amplification was performed in a Veriti 96 well Thermal Cycler (Applied Biosystems) with an initial temperature at $94{ }^{\circ} \mathrm{C}$ for $2 \mathrm{~min}, 30$ cycles at $94{ }^{\circ} \mathrm{C}$ for $1 \mathrm{~min}, 55^{\circ} \mathrm{C}$ for $1 \mathrm{~min}$ and $72{ }^{\circ} \mathrm{C}$ for $3 \mathrm{~min}$. A final extension at $72{ }^{\circ} \mathrm{C}$ was included for $10 \mathrm{~min}$. The PCR products were purified with a GFX PCR DNA and gel band purification kit (GE Healthcare), and the sequence analysis was performed using a 3500 Genetic Analyzer Sequencer (Applied Biosystems). Subsequently, 5.0 $\mu \mathrm{L}$ purified PCR product was mixed with $4.0 \mu \mathrm{L}$ of BigDye v. 3.1 (Applied Biosystems) and $1.0 \mu \mathrm{L}$ sequencing primer $(0.5 \mu \mathrm{mol})$. The primers used in the sequencing reactions were $27 \mathrm{f}$ (Dojka et al., 1998), 782r (5ACCAGGGTATCTAATCCTGT3) (Chun and Goodfellow, 1995) and 1401r (5CGGTGTGTACAAGACC C3) (Nübel et al., 1996). The sequencing program consisted of 25 cycles at $95{ }^{\circ} \mathrm{C}$ for $20 \mathrm{~s}, 50^{\circ} \mathrm{C}$ for $15 \mathrm{~s}$ and $60{ }^{\circ} \mathrm{C}$ for $60 \mathrm{~s}$. The $16 \mathrm{~S}$ rRNA gene sequence of all the analyzed strains was compared to bacterial sequences deposited in GenBank. Sequences with similarity were retrieved, and the consensus sequences were aligned using CLUSTALW with MEGA 5.05. EzTaxon tools (http://147.47.212.35:8080/) were further employed to confirm the similarities, and phylogenetic trees were constructed based on neighbor-joining, maximumlikelihood and maximum-parsimony methods. The resulting tree topologies were evaluated by a bootstrap analysis based on 1000 replicates.

\section{Nucleotide sequence accession numbers}

The sequenced strains SR5-6, SR5-7, SR5-12, YPC-6, YPC-8, YPC-11, YPC-13 and YPC-15 were deposited in GenBank under accession numbers JX154082, JX154083, JX154084, JX154085, JX154086, JX154087, JX154088 and JX154089, respectively.

\section{Results and Discussion}

\section{Identification of halophilic strains}

The isolated bacteria were obtained from the composting process during the turning stage $\left(60^{\text {th }}\right.$ day). Eight out of eleven halophilic isolates in $2.5 \mathrm{M} \mathrm{NaCl}$ from the composting process were subjected to a MALDI-TOF mass spectrometry analysis, which indicated that the genera of all isolates were Gram positive, which was confirmed by Gram staining. These procedures ensured and confirmed the purity of the isolates. The $16 \mathrm{~S}$ rRNA gene sequences of eight strains ( $>$ than $1300 \mathrm{bp}$ ) were compared with those previously deposited in GenBank. The neighbor-joining and maximum-likelihood trees showed the taxonomic position of these strains, which were affiliated with Bacillus, Staphylococcus and Brevibacterium genera (Figure 2).

Strain SR5-7 showed high 16S rRNA gene sequence similarity to Bacillus when compared with the 184 different species of this genus. However, based on the similarity matrix of the 16S rRNA gene, this isolate did not show $100 \%$ similarity with any of the species already reported. The species of Bacillus described as halophilic to date are as follows: B. hemicentroti (Chen et al., 2011); B. humanensis (Chen et al., 2011); B. xianensis (Sanchez-Porro et al., 2003; Schlegel et al., 1970); B. alkaliphilic (Zhang et al., 2012); B. halochares (Pappa et al., 2010); B. chungangensis (Cho et al., 2010) and B. subtilis (Takenaka et al., 2011). Thus, the possibility that a new species of halophilic Bacillus was isolated from a compost process is noteworthy.

The YPC-11 strain was identified as Brevibacterium avium (100\% similarity). An EzTaxon analysis confirmed that this strain shared $100 \% 16 \mathrm{~S}$ rRNA gene sequence similarity with B. avium and $99.97 \%$ with Brevibacterium epidermidis, the only halotolerant bacterium (Nagata and Wang, 2005) described in the genus Brevibacterium.

Strains SR5-12, SR5-6, YPC-6, YPC-8, YPC-13 and YPC-15 were classified as members of the Staphylococcus genus. The isolates SR5-12 and SR5-6 showed 100\% 16S rRNA gene sequence similarity with $S$. lentus and $S$. sciuri, respectively, a result that was confirmed by EzTaxon. However, to date, these species have not been described as high salt concentration-tolerant bacteria, with the only species of Staphylococcus known as halophilic being Staphylococcus equorum (Essghaier et al., 2009).

All the selected isolates were deposited at the São Paulo Zoo Park Culture Collection (SPZSP-CCol).

\section{Salt tolerance and growth of halophilic isolates}

All the bacteria isolated in $2.5 \mathrm{M} \mathrm{NaCl}$ were tested for their ability to grow at different salt concentrations. A slowing of bacterial growth was observed in the presence of high salt concentrations, as indicated by the time (in days) required for detecting the presence of bacteria in the culture medium (Table 1). Staphylococcus strains SR5-12, YPC-6, SR5-6 and YPC-8 showed similar growth behavior from 0 to $4.0 \mathrm{M} \mathrm{NaCl}$. Strain YPC-13 had the slowest growth at high salinity, and strain YPC-15 grew preferentially at 2.5 $\mathrm{M} \mathrm{NaCl}$ or higher. Bacillus strains SR5-7 and YPC-11 (affiliated with B. avium) exhibited a preference for growing in a culture medium containing 0.5 to $2.0 \mathrm{M} \mathrm{NaCl}$ but failed to grow in $4.0 \mathrm{M} \mathrm{NaCl}$. It is important to note that although all of these bacteria tolerated high salinities $(2.5 \mathrm{M}$ $\mathrm{NaCl}$ or higher), they are not strictly halophilic bacteria. According to Kushner (1978), bacteria that are able to grow in the absence of salt as well as in the presence of relatively high salt concentrations are designated halotolerant or ex- 
tremely halotolerant if growth extends above $2.5 \mathrm{M}$. Based on this classification, seven out of the eight isolated microorganisms isolated from composting process were halotolerant or extremely halotolerant. It should be noted that the salt requirement and tolerance of many species vary according to the growth conditions, such as temperature and medium composition.

Several bacteria of Bacillus, Halobacillus and Staphylococcus have been found in saline environments, such as Salt Plains National Wildlife Refuge, Great Salt Plains of Oklahoma, a Bolivian hypersaline lake, deep-sea sediments and tropical marine sediments (Ventosa et al., 1998). Some species of Bacillus sp. are salt tolerant and are important degraders of organic pollutants. Examples include Bacillus cereus, which degrades 1,3-dichlorobenzene derivatives from town-gas industrial influent (Wang et al., 2003), and
Bacillus subtilis, which degrades p-aminobenzene from textile industry wastewater (Zissi et al., 1997).

\section{Hydrolytic activities of halotolerant isolates}

The SR5-6, SR5-7, SR5-12, YPC-8, YPC-11 and YPC-15 strains were found to be moderate halophilic microorganisms and showed combined cellulolytic, amylolytic, lipolytic and proteolytic activities (Table 1). These strains have potential biotechnological applications with respect to their ability to produce different hydrolases (Rohban et al., 2009). In contrast, no hydrolytic activity was observed for YPC-6 and YPC-13.

Only YPC-11 (affiliated with B. avium) presented amylase and cellulase hydrolytic activities from 0 to $4 \mathrm{M}$ $\mathrm{NaCl}$. Members of the genus Bacillus are well known enzyme producers, and many industrial processes utilize species belonging to this genus for the commercial production
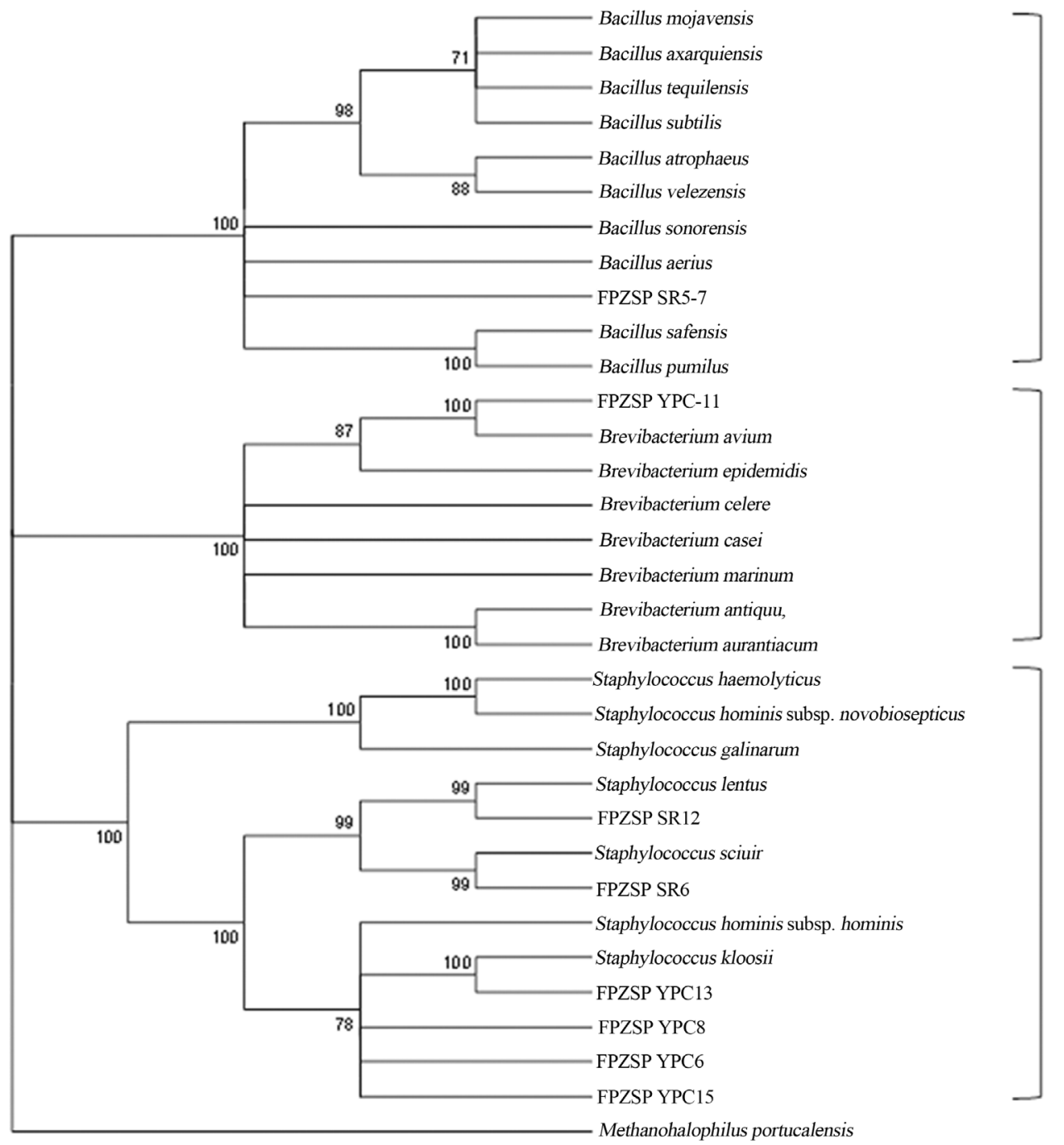

Bacillus group

Brevibacterium group

Staphylococcus group

Figure 2 - Phylogenetic tree showing the position of the halotolerant isolates, as based on a partial 16S rRNA gene sequence comparison obtained by neighbor-joining and maximum-likelihood trees. The nucleotide sequence accession numbers were deposited in GenBank, as described in Material and Methods. 

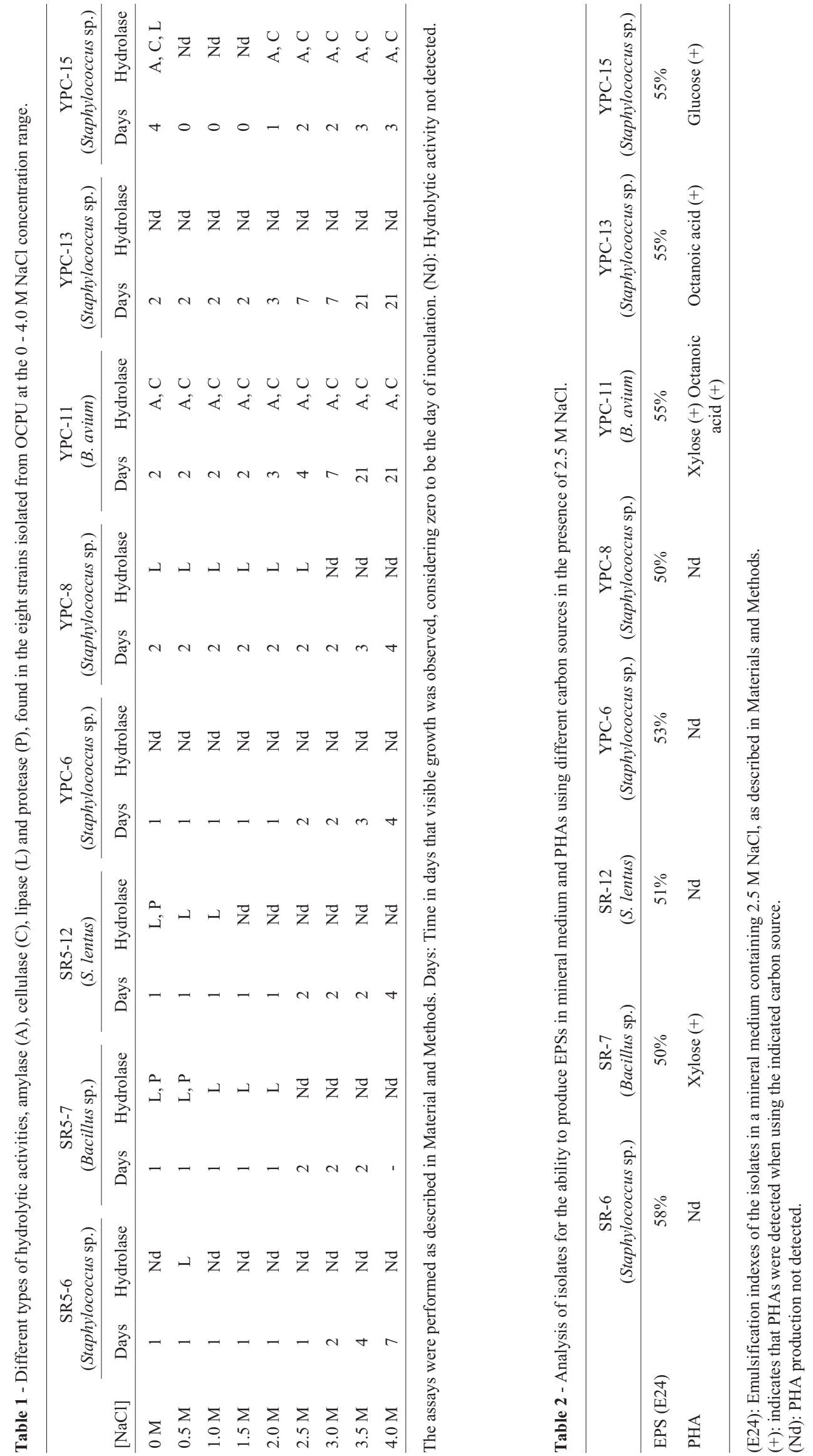
of enzymes (Vasconcellos et al., 2011). The strain SR5-7 (affiliated with Bacillus) produced lipase and protease in $2.0 \mathrm{M}$ and $0.5 \mathrm{M} \mathrm{NaCl}$, respectively. It is interesting to note that the lipase producers reported thus far are limited to representatives of the genera Salinivibrio, Halomonas and $\mathrm{Ba}$ cillus-Salibacillus (Sanchez-Porro et al., 2003).

\section{Polyhydroxyalkanoate (PHA) producers}

All the isolates were evaluated using a medium with nitrogen limitation and different carbon sources (Table 2). The isolates grew better with glucose as the sole carbon source compared to xylose and octanoic acid. The isolates YPC-13 (affiliated with Bacillus sp.), SR5-7 (affiliated with Bacillus sp.) and YPC-15 (affiliated with Staphylococcus sp.) accumulated PHAs in presence of octanoic acid, xylose and glucose, respectively. The genus Bacillus is known as a producer of PHAs (Lopes et al., 2009), and Staphylococcus epidermidis, which was isolated from sesame oil, presented the ability to produce poly-3-hydroxybutyrate (Wong et al., 2000). The strain YPC-11 (affiliated with $B$. avium) was detected as a potential producer of biopolymers using octanoic acid and xylose. This result is in accordance with the previous observation that Brevibacterium casei (SRKP2 strain) could produce PHAs in a medium containing dairy industrial waste, yeast extract and sea water (Pandian et al., 2009). Halotolerant microbes are important for the biotechnology industry due to their advantages for use in sterilization processes and the control of contaminants; the PHA-producing halophilic microorganisms have recently been reviewed (Poli et al., 2011). The production of PHAs using xylose is an alternative strategy to produce economically competitive PHAs using agro-industrial products such as sugarcane molasses and bagasse (Gomez et al., 2012).

\section{EPS production and emulsification potential}

Microbial exopolymers (EPSs) correspond to compounds produced by microorganisms to solubilize essential nutrients for their survival or to promote their adherence onto surfaces (Ron and Rosenber, 2002). The use of glycerol as a sole carbon source and $2.5 \mathrm{M} \mathrm{NaCl}$ resulted in EPS values up to $60 \%$ of the emulsification index (E24) of hexadecane (Table 2). A colorimetric analysis showed that the biosurfactant produced by the evaluated halotolerant strains were mainly composed of carbohydrates $(95 \%)$ but also contained proteins $(0.5 \%)$ and uronic acids $(4.5 \%)$ in their composition. A similar EPS composition was also reported in halophilic Archaea strains (Poli et al., 2011).

\section{Conclusion}

Screens for halotolerant or halophilic microorganisms in non-saline environments are scarce as is the detection of extracellular enzymes. This study found eight isolates from an organic residue composting process that showed the ability to tolerate a wide range of salinity. Some of these strains presented combined hydrolytic ability in the presence of $\mathrm{NaCl}$. The possibility of these microorganisms, particularly YPC-11 (affiliated with B. avium), to produce EPSs and PHAs in the presence of $2.5 \mathrm{M} \mathrm{NaCl}$ can offer new biotechnological and bioremediation perspectives for the treatment of oilfield wastes as well as in MEOR (microbial-enhanced oil recovery) processes. The performance of the halotolerant isolates in the present work were not compared to other already known and classic halophilic microorganisms, and this should be performed in future work.

\section{Acknowledgments}

This study was supported by the Brazilian research agencies Fundação de Amparo a Pesquisa do Estado de São Paulo (FAPESP - 2009/52030-5) and Conselho Nacional de Desenvolvimento Científico e Tecnológico (CNPq 471340/2011-1). The authors would like to express their gratitude to Fundação Parque Zoológico de São Paulo for providing the material from its composting facility and to recognize the relevant participation and support of Mr. Robson Carlos Santos and Mr. Carlos Augusto Magalhães Batista, at Fundação Parque Zoológico de São Paulo, in the composting unit processes.

\section{References}

Ben-Gigirey B, de Sousa JMVB, Villa TG et al. (2000) Characterization of biogenic amine-producing Stenotrophomonas maltophilia strains isolated from white muscle of fresh and frozen albacore tuna. Int J Food Microbiol 57:19-31.

Chen YG, Hao DF, Chen QH et al. (2011) Bacillus hunanensis sp nov., a slightly halophilic bacterium isolated from nonsaline forest soil. Antonie Van Leeuwenhoek Int J Genet Mol Microbiol 99:481-488.

Chen YG, Zhang YQ, He JW et al. (2011) Bacillus hemicentroti sp. nov., a moderate halophile isolated from a sea urchin. Int J Syst Evol Microbiol 61:2950-2955.

Cho SL, Jung MY, Park MH et al. (2010) Bacillus chungangensis sp. nov., a halophilic species isolated from sea sand. Int J Syst Evol Microbiol 60:1349-1352.

Chun J, Goodfellow M (1995) A phylogenetic analysis of the genus Norcadia with 16S rDNA gene sequences. Int J Syst Bacteriol 45:240-245.

Dojka MA, Hugenholtz P, Haack SK et al. (1998) Microbial diversity in a hydrocarbon-and chlorinated-solvent-contaminated aquifer undergoing intrinsic bioremediation. Appl Environ Microbiol 64:3869-3877.

Enache M, Kamekura M (2010) Hydrolytic enzymes of halophilic microorganisms and their economic values. Rom J Biochem 47:47-59.

Essghaier B, Fardeau ML, Cayol JL et al. (2009) Biological control of grey mould in strawberry fruits by halophilic bacteria. J Appl Microbiol 106:833-846.

Fleck LC, Bicca FC, Ayub MAZ (2000) Physiological aspects of hydrocarbon emulsification, metal resistance and DNA profile of biodegrading bacteria isolated from oil polluted sites. Biotechnol Lett 22:285-289. 
Fuciños P, Gonzalez R, Atanes E et al. (2012) Lipases and esterases from extremophiles: overview and case example of the production and purification of an esterase from Thermus thermophilus HB27. Methods Mol Biol 861:239-266.

Gomez J, Mendez B, Nikel P et al. (2012) Making Green polymers even greener: Towards sustainable production of polyhydroxyalkanoates from agroindustrial by-products. In: Petre, M (ed) Adv Appl Biotechnol InTech Publisher, p. 41-62.

Gupta R, Beg QK, Lorenz P (2002) Bacterial alkaline proteases: molecular approaches and industrial applications. Appl Microbiol Biotechnol 59:15-32.

Kushner DJ (1978) Life in High Salt and Solute Concentrations: Halophilic Bacteria. Academic Press, London.

Legat A, Gruber C, Zangger K et al. (2010) Identification of polyhydroxyalkanoates in Halococcus and other haloarchaeal species. Appl Microbiol Biotechnol 87:1119-1127.

Li X, Yu HY (2011) Extracellular production of beta-amylase by a halophilic isolate, Halobacillus sp. LY9. J Ind Microbiol Biotechnol 38:1837-1843.

Litchfield CD (2012) Potential for industrial products from the halophilic Archaea. J Ind Microbiol Biotechnol 38:16351647.

Lopes MSG, Rocha RCS, Zanotto SP et al. (2009) Screening of bacteria to produce polyhydroxyalkanoates from xylose. World J Microbiol Biotechnol 25:1751-1756.

Martins LF, Antunes LP, Pascon RC et al. (2013) Metagenomic analysis of a tropical composting operation at the São Paulo zoo park reveals diversity of biomass degradation functions and organisms. PLoS One 8:e61928.

Nagata S, Wang CX (2005) Efficient utilization of ectoine by halophilic Brevibacterium species and Escherichia coli subjected to osmotic down shock. J Biosci Bioeng 99:61-67.

Nübel U, Engelen B, Felske A et al. (1996) Sequence heterogeneities of genes encoding 16S rRNAs in Paenibacillus polymyxadetected by temperature gradient gel electrophoresis. J Bacteriol 178:5636-5643.

Pandian SRK, Deepak V, Kalishwaralal K et al. (2009) Synthesis of PHB nanoparticles from optimized medium utilizing dairy industrial waste using Brevibacterium casei SRKP2: A green chemistry approach. Colloids Surf. B-Biointerfaces 74:266-273.

Pappa A, Sanchez-Porro C, Lazoura P et al. (2010) Bacillus halochares sp. nov., a halophilic bacterium isolated from a solar saltern. Int J Syst Evol Microbiol 60:1432-1436.

Partanen P, Hultman J, Paulin L et al. (2010) Bacterial diversity at different stages of the composting process. BMC Microbiol 10:1-11.

Pascon RC, Bergamo RF, Spinelli RX et al. (2011) Amylolytic Microorganism from São Paulo Zoo Composting: Isolation, Identification, and Amylase Production. Enzym Res 2011:679624.

Poli A, Di Donato P, Abbamondi GR et al. (2011) Synthesis, Production, and Biotechnological Applications of Exopolysaccharides and Polyhydroxyalkanoates by Archaea. Archaea 2011:693253.
Prakash B, Vidyasagar M, Madhukumar MS et al. (2009) Production, purification, and characterization of two extremely halotolerant, thermostable, and alkali-stable alpha-amylases from Chromohalobacter sp TVSP 101. Process Biochem 44:210-215.

Rohban R, Amoozegar MA, Ventosa A (2009) Screening and isolation of halophilic bacteria producing extracellular hydrolases from Howz Soltan Lake, Iran. J Ind Microbiol Biotechnol 36:333-340.

Ron EZ, Rosenberg E (2002) Biosurfactants and oil bioremediation. Curr Opin Biotechnol 13:249-252.

Sanchez-Porro C, Martin S, Mellado E, Ventosa A (2003) Diversity of moderately halophilic bacteria producing extracellular hydrolytic enzymes. J Appl Microbiol 94:295-300.

Schlegel HG, Lafferty R, Krauss I (1970) Isolation of mutants not accumulating poly-beta-hydroxybutyric acid. Arch Für Mikrobiol 71:283-294.

Schloss PD, Hay AG, Wilson DB et al. (2003) Tracking temporal changes of bacterial community fingerprints during the initial stages of composting. FEMS Microbiol Ecol 46:1-9.

Takenaka S, Yoshida N, Yoshida K et al. (2011) Molecular cloning and sequence analysis of two distinct halotolerant extracellular proteases from Bacillus subtilis FP-133. Biosci Biotechnol Biochem 75:148-151.

Tanasupawat S, Chamroensaksri N, Kudo T et al. (2010) Identification of moderately halophilic bacteria from Thai fermented fish (pla-ra) and proposal of Virgibacillus siamensis sp. nov. J Gen Appl Microbiol 56:369-379.

Vasconcellos SP, Dellagnezze BM, Wieland A et al. (2011). The potential for hydrocarbon biodegradation and production of extracellular polymeric substances by aerobic bacteria isolated from a Brazilian petroleum reservoir. World J Microbiol Biotechnol 27:1513-1518.

Ventosa A, Nieto JJ (1995) Biotecnological applications and potentialities of halophilic microrganisms. World J Microbiol Biotechnol 11:85-94.

Ventosa A, Nieto JJ, Oren A (1998) Biology of moderately halophilic aerobic bacteria. Microbiol Mol Biol Rev 62:504-544.

Voget S, Steele HL, Streit WR (2006) Characterization of a metagenome-derived halotolerant cellulase. J Biotechnol 126:26-36.

Wang L, Zhou Q, Zhang BS et al. (2003) The biodegradation of 1,3-dichlorobenzene by an adapted strain Bacillus cereus PF-11 derived from town-gas industrial effluent. J Environ Sci Health Part A 38:1837-1848.

Wong AL, Chua H, Yu pH (2000) Microbial production of polyhydroxyalkanoates by bacteria isolated from oil wastes. Appl Biochem Biotechnol 84-86:843-857.

Zhang GM, Li SY, Xue YF et al. (2012) Effects of salts on activity of halophilic cellulase with glucomannanase activity isolated from alkaliphilic and halophilic Bacillus sp. BG-CS10. Extremophiles 16:35-43.

Zissi U, Lyberatos G, Pavlou S (1997) Biodegradation of p-aminoazobenzene by Bacillus subtilis under aerobic conditions. J Ind Microbiol Biotechnol 19:49-55.

\section{Associate Editor: Cynthia Canêdo da Silva}

All the content of the journal, except where otherwise noted, is licensed under a Creative Commons License CC BY-NC. 